\title{
LCAT deficiency as a cause of proteinuria and corneal opacification
}

\author{
Enrique Morales, ${ }^{1}$ Marina Alonso, ${ }^{2}$ Beatriz Sarmiento, ${ }^{3}$ Montserrat Morales ${ }^{4}$
}

'Department of Nephrology, Hospital Universitario 12 de Octubre, Madrid, Spain ${ }^{2}$ Department of Pathology, Hospital Universitario 12 de Octubre, Madrid, Spain ${ }^{3}$ Department of Ophthalmology, Hospital Universitario 12 de Octubre, Madrid, Spain ${ }^{4}$ Department of Internal Medicine, Hospital Universitario 12 de Octubre, Madrid, Spain

\section{Correspondence to} Dr Enrique Morales, emoralesr@senefro.org

EM and MM contributed equally.

Accepted 22 February 2018

\section{DESCRIPTION}

A 44-year-old woman was diagnosed with corneal dystrophy (figure 1) and anaemia. Analytically, she showed an altered lipid profile (cholesterol $172 \mathrm{mg}$ / $\mathrm{dL}$, triglycerides $173 \mathrm{mg} / \mathrm{dL}$, high-density lipoprotein (HDL) cholesterol $6.6 \mathrm{mg} / \mathrm{dL}$, low-density lipoprotein cholesterol $131 \mathrm{mg} / \mathrm{dL}$, very low-density lipoprotein (VLDL) cholesterol $45 \mathrm{mg} / \mathrm{dL}$, VLDL triglycerides $143 \mathrm{mg} / \mathrm{dL}$, apo A $62 \mathrm{mg} / \mathrm{dL}$, apo $\mathrm{B} 69.6 \mathrm{mg} / \mathrm{dL}$, lipoprotein $\mathrm{A}<2.5 \mathrm{mg} / \mathrm{dL}$ ) and proteinuria between 1 and $2 \mathrm{~g} /$ day. A renal biopsy was performed. Histology revealed the presence of segmental hyaline lesions and irregular mesangial enlargement. Glomerular capillary walls showed parietal thickening and subendothelial deposits, vacuolisation and frequent images of reduplication of the basement membrane (figure 2). Electron microscopy showed lipid deposition in many areas (figure 3). The evaluation of the plasma lecithin cholesterol acyltransferase (LCAT) enzymatic activity was $15.2 \mathrm{nmol} / \mathrm{mL} /$ hour (reference range, $81 \pm 12 \mathrm{~mL} / \mathrm{min} /$ hour). A genetic study of LCAT deficiency disease was performed which showed a missense homozygosis in the LCAT gene c368G > Cp (R123p), not previously described in literature.

Complete LCAT deficiency disorder is a very rare condition with an incidence rate of less than 1 in 1 million individuals. This disorder is caused by a mutation in the LCAT gene. The LCAT gene encodes the enzyme LCAT, which binds blood and tissue cholesterol to lipoproteins in order to transport it to the liver. ${ }^{1}$ The signs and symptoms include corneal opacification, haemolytic anaemia and proteinuria. Kidney disease is the major cause

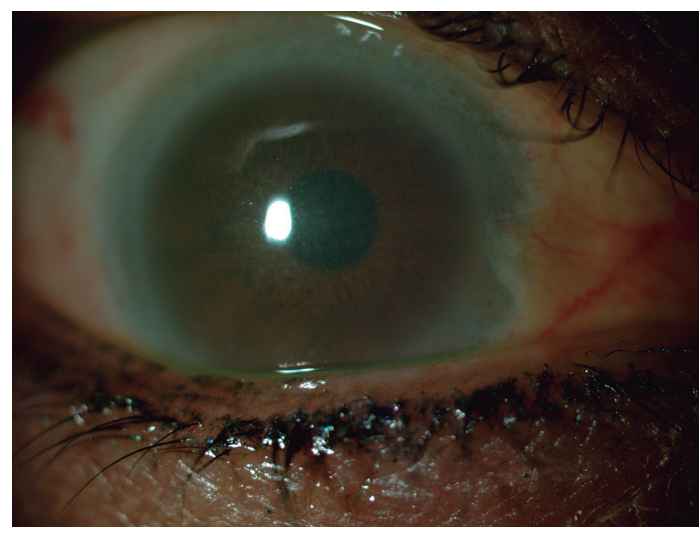

To cite: Morales $\mathrm{E}$, Alonso $\mathrm{M}$ Sarmiento $\mathrm{B}$, et al. BMJ Case Rep Published Online First: [please include Day Month Year]. doi:10.1136/bcr-2017224129

Figure 1 Slit lamp image of eye demonstrating corneal opacification. Cornea shows generalised haziness in stromal layer with accentuation at the periphery forming

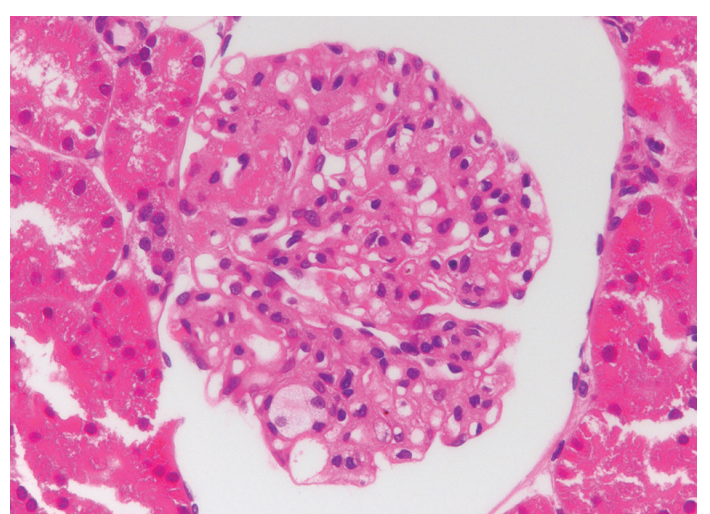

Figure 2 H\&E shows mesangial expansion, thickening of the capillary walls and foam cells filling the capillary lumina.

of morbidity in these patients. Hypertension and progressive deterioration of renal function leading to end-stage of renal disease are frequent and need renal replacement therapy. ${ }^{2}$ Characteristic analytical findings include an abnormal lipid profile with markedly decreased HDL cholesterol, apo A and apo B values and increased triglycerides. ${ }^{3}$ There is no established treatment for this entity; however, the infusion of recombinant human LCAT has been tried with favourable results: improvement of anaemia, normalisation

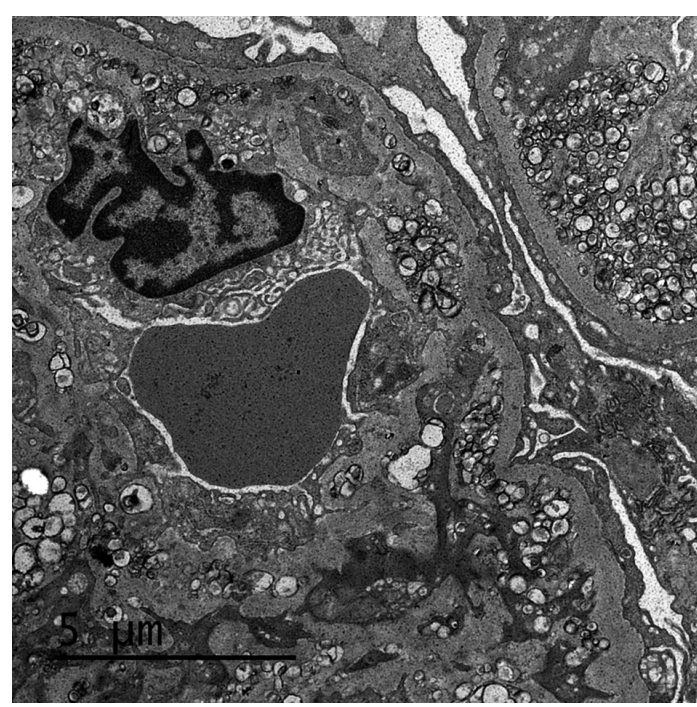
a circumferential corneal arcus.
Figure 3 Electron microscopy shows subendothelial, intramembranous and mesangial electron-dense, rounded lamellar deposits. 


\section{Learning points}

Lecithin cholesterol acyltransferase (LCAT) deficiency disorder is an extremely rare genetic disorder.

- The patients with LCAT deficiency have an abnormal lipid profile (very low levels of high-density lipoprotein cholesterol, apo A1 and apo B).

- LCAT deficiency disorder includes proteinuria and progressive chronic kidney disease and fat deposits in the corneas of the eyes.

of HDL cholesterol and slowing progression of chronic kidney disease.

Contributors EM: drafting the article or revising it critically for important intellectual content. MA and BS: conception and design, acquisition of data, or analysis and interpretation of data. MM: final approval of the version published.
Funding The authors have not declared a specific grant for this research from any funding agency in the public, commercial or not-for-profit sectors.

Competing interests None declared.

Patient consent Obtained.

Provenance and peer review Not commissioned; externally peer reviewed.

(C) BMJ Publishing Group Ltd (unless otherwise stated in the text of the article) 2018. All rights reserved. No commercial use is permitted unless otherwise expressly granted.

\section{REFERENCES}

1 Savel J, Lafitte M, Pucheu Y, et al. Very low levels of HDL cholesterol and atherosclerosis, a variable relationship--a review of LCAT deficiency. Vasc Health Risk Manag 2012:8:357-61.

2 Weber CL, Frohlich J, Wang J, et al. Stability of lipids on peritoneal dialysis in a patient with familial LCAT deficiency. Nephrol Dial Transplant 2007;22:2084-8.

3 Shamburek RD, Bakker-Arkema R, Auerbach BJ, et al. Familial lecithin:cholesterol acyltransferase deficiency: First-in-human treatment with enzyme replacement. J Clin Lipidol 2016;10:356-67.

Copyright 2018 BMJ Publishing Group. All rights reserved. For permission to reuse any of this content visit http://group.bmj.com/group/rights-licensing/permissions.

BMJ Case Report Fellows may re-use this article for personal use and teaching without any further permission.

Become a Fellow of BMJ Case Reports today and you can:

- Submit as many cases as you like

- Enjoy fast sympathetic peer review and rapid publication of accepted articles

- Access all the published articles

- Re-use any of the published material for personal use and teaching without further permission

For information on Institutional Fellowships contact consortiasales@bmjgroup.com

Visit casereports.bmj.com for more articles like this and to become a Fellow 